\title{
PLASMID DNA IN THE ERYTHROMYCIN PRODUCING MICROORGANISM, STREPTOMYCES ERYTHREUS NRRL 2338
}

\author{
Wang Yi-guang, * Julian E. Davies, ** \\ and C. Richard Hutchinson*** \\ Department of Biochemistry, University of Wisconsin, \\ Madison, WI 53706, U.S.A.
}

(Received for publication October 19, 1981)

\begin{abstract}
Streptomyces erythreus NRRL 2338, the erythromycin producing microorganism, contains extrachromosomal (plasmid) DNA. Four different plasmids, pSE1, pSE2, pSE4 and pSE6 present in the wild-type strain have characteristic mobilities on agarose gel electrophoresis, molecular weights and restriction endonuclease digestion patterns. Treatment of the wildtype strain with ethidium bromide or acridine orange gave two variants, one that could not convert erythronolide B to $3(\alpha)$-mycarosylerythronolide B and another that produced $2 \sim 3$ times more erythromycin A than the parental strain. Although the plasmid DNA profile of these two variants is different from the wild-type strain, it is not possible to conclude that any of the structural genes for erythromycin biosynthesis are located on the plasmids of $S$. erythreus NRRL 2338.
\end{abstract}

There is much interest concerning the possible involvement of plasmid DNA in the production of antibiotics by streptomycetes. Observations that high frequency loss of antibiotic production can occur upon treatment with chemical "curing" agents, ${ }^{1 \sim 6)}$ and that plasmid DNA is present in several species of these bacteria ${ }^{6 \sim \vartheta)}$ circumstantially supports the possibility that genetic control of antibiotic formation may be located on plasmid DNA in some cases. Convincing demonstrations of this presumption are limited; for example, in Streptomyces coelicolor, where genetic ${ }^{10)}$ and physical analysis (J. WestPHeLING and D. A. Hopwood, unpublished results) has shown that the structural genes for methylenomycin production are born by the SCP1 plasmid.

We are investigating the molecular genetics of erythromycin A formation in Streptomyces erythreus NRRL 2338 to determine the location of the genes that encode the information for its biosynthesis. This 14-membered macrolide antibiotic is made ${ }^{11)}$ in three principal stages: formation of the lactone ring and two sugars, their assembly to erythromycin $\mathrm{D}$, and its processing by $C$-oxidation and $O$-methylation to give erythromycin A. Because most of the steps of the biosynthetic pathway to erythromycin A are known, we can focus on single phenotypic events for the genetic analysis of S. erythreus. Thus we chose to study the plasmids of S. erythreus NRRL 2338 to determine if they carry structural genes that encode information for any of the enzymes governing the formation of erythromycin A.

We now describe methods for the isolation of several plasmids from a wild-type strain of S. erythreus NRRL 2338 and their partial physical characterization. This is the first report of plasmid DNA in a bacterial strain that produces 14-membered macrolide antibiotics. Our findings contrast those of OMURA et al. ${ }^{12)}$ who reported recently that two other wild-type strains of S. erythreus did not harbor plas-

Present addresses: *Institute of Antibiotics, Chinese Academy of Medical Sciences, Beijing, The Peoples Republic of China. **Biogen SA, 1227 Carouge, Switzerland. ***School of Pharmacy, University of Wisconsin, Madison, WI 53706. Address correspondence to this author. 
mid DNA. We also note some preliminary observations about the relationship between the plasmid profile and antibiotic production phenotype of S. erythreus NRRL 2338.

\section{Materials and Methods}

Strain and Culture Conditions

Streptomyces erythreus NRRL 2338 was obtained from the culture collection of the Northern Regional Research Laboratory, Agricultural Research Service, Peoria, Illinois, USA. Cultures were maintained on a modified Okanishi R2 slant medium ${ }^{24)}$ consisting of sucrose (103 g), $\mathrm{K}_{2} \mathrm{SO}_{4}(0.25 \mathrm{~g})$, Difco yeast extract (4 g), Difco peptone (4 g), Difco Bacto agar (22 g), and water ( $800 \mathrm{ml})$. After autoclaving, the stated volumes of the following sterile solutions were added to make up the complete medium $50 \%$ glucose $(20 \mathrm{ml})$, TES buffer (Sigma Chemical Co., $0.25 \mathrm{M}, \mathrm{pH} 7.2,100 \mathrm{ml}), \mathrm{KH}_{2} \mathrm{PO}_{4}(0.5 \%, 5 \mathrm{ml})$, $\mathrm{NaOH}(1 \mathrm{M}, 2.5 \mathrm{ml}), \mathrm{CaCl}_{2}(1 \mathrm{M}, 50 \mathrm{ml}), \mathrm{MgCl}_{2}(1 \mathrm{M}, 50 \mathrm{ml})$ and trace elements $\left(\mathrm{ZnCl}_{2}, 40 \mathrm{mg} ; \mathrm{FeCl}_{3}\right.$. $6 \mathrm{H}_{2} \mathrm{O}, 200 \mathrm{mg} ; \mathrm{CuCl}_{2} \cdot 2 \mathrm{H}_{2} \mathrm{O}, 10 \mathrm{mg} ; \mathrm{MnCl}_{2} \cdot 4 \mathrm{H}_{2} \mathrm{O}, 10 \mathrm{mg} ; \mathrm{Na}_{2} \mathrm{~B}_{4} \mathrm{O}_{7} \cdot 10 \mathrm{H}_{2} \mathrm{O}, 10 \mathrm{mg} ;\left(\mathrm{NH}_{4}\right)_{8} \mathrm{Mo}_{7} \mathrm{O}_{24}$. $4 \mathrm{H}_{2} \mathrm{O}, 10 \mathrm{mng}$ per $1000 \mathrm{ml} \mathrm{H} \mathrm{H}_{2} \mathrm{O} ; 2 \mathrm{ml}$ ). Spore suspensions were prepared by washing slants with $20 \%$ glycerol containing $0.1 \%$ Triton X-100, filtering through non-absorbant cotton, centrifuging and washing the pelleted spores twice with $20 \%$ glycerol. These spore suspensions were stored at $-80^{\circ} \mathrm{C}$ in $20 \%$ glycerol. Cultures were grown in YEME-sucrose medium ${ }^{14)}$, or in TSB medium (Difco tryptic soy broth) at $30^{\circ} \mathrm{C}$ for plasmid isolation.

\section{Chemicals and Reagents}

Sodium dodecyl sulfate (SDS), Tris, PEG 6000, diethyl pyrocarbonate (DEP), EDTA, ethidium bromide, and lysozyme (egg white, grade 1) were purchased from Sigma Chemical Co., St. Louis, MO. Technical grade $\mathrm{CsCl}$ was purchased from Kawecki Berylco Industries, Inc., Glenn Ellyn, IL, USA. The solution of phenol - chloroform $(1: 1, \mathrm{v} / \mathrm{v})$ and the lysing solution containing $3 \%$ SDS and $50 \mathrm{~mm}$ tris ( $\mathrm{pH}$ 12.6) were prepared according to KADO and LuI. ${ }^{13)}$ TE buffer consisted of $0.01 \mathrm{M}$ tris, $0.001 \mathrm{M}$ EDTA, pH 8.0. TES buffer contained $0.03 \mathrm{M}$ tris $\cdot \mathrm{HCl}, 0.005 \mathrm{~m}$ EDTA and $0.05 \mathrm{M} \mathrm{NaCl}, \mathrm{pH}$ 8.0. DNA buffer contained $0.01 \mathrm{M}$ tris $\cdot \mathrm{HCl}, 10^{-4} \mathrm{M}$ EDTA and $0.01 \mathrm{M} \mathrm{NaCl}, \mathrm{pH} 7.9$.

\section{Gel Electrophoresis}

Agarose gel electrophoresis was performed in 0.7 to $0.8 \%$ agarose gels (Miles Laboratories, Elkhart, USA) using the horizontal apparatus described by MCDONELL et al. ${ }^{23)}$ Gels were made and run in a $40 \mathrm{~mm}$ tris, $20 \mathrm{~mm} \mathrm{NaOAc}, 1 \mathrm{~mm} \mathrm{Na}{ }_{4}$ EDTA buffer whose $\mathrm{pH}$ was adjusted to 8.0 with glacial acetic acid (E buffer). Electrophoresis was carried out at $1 \sim 5 \mathrm{~V} / \mathrm{cm}$ for $5 \sim 18$ hours at ambient temperature using bromphenolblue $(0.1 \%)$ in $50 \%$ glycerol as a tracking dye. The gel (4 mm thick) was then stained with ethidium bromide $(1 \mu \mathrm{g} / \mathrm{ml})$ for 30 minutes at ambient temperature. Photographs were taken of gels that were positioned over a shortwave UV light source (Ultraviolet Products, Inc., San Gabriel, CA, USA), using Polaroid type 55 film exposed through a Tiffen 15 orange filter.

Vertical gel electrophoresis was done in $6 \mathrm{~mm}$ I.D. glass tubes containing $0.75 \%$ low gelling temperature agarose (Miles Laboratories) in E buffer. Electrophoresis was carried out at $1.5 \mathrm{~mA}$ /tube for 16 18 hours at ambient temperature. Staining and photography were done as described above.

\section{Plasmid DNA Detection Procedure}

YEME or TSB medium $(5 \mathrm{ml})$ in $20 \mathrm{ml}$ test tubes was inoculated with a dense suspension $(0.1 \mathrm{ml})$ of spores. The cultures were incubated at $30^{\circ} \mathrm{C}, 350 \mathrm{rpm}$, in an NBS G24 shaker (New Brunswick Scientific Co., Edison, NJ, U.S.A.) for 3 to 4 days until reaching the stationary phase of growth. The mycelia were recovered by centrifugation in a $15 \mathrm{ml}$ conical tube (Corning No. 25310) at 4,000 rpm for 15 minutes at $4{ }^{\circ} \mathrm{C}$ and then washed once by centrifugation with TE buffer containing $15 \%$ sucrose. After decanting the supernatant, the mycelial pellet was suspended in TE buffer containing $15 \%$ sucrose $(100 \mu 1)$, mixed with $50 \mu \mathrm{l}$ of a freshly prepared solution of lysozyme $(50 \mathrm{mg} / \mathrm{ml})$ in TE buffer, and incubated at $30^{\circ} \mathrm{C}$ until the cells became flocculant but not lysed. A $200 \mu \mathrm{l}$ aliquot of this mixture was transferred to a $1.5 \mathrm{ml}$ Eppendorf tube and mixed with $400 \mu \mathrm{l}$ of the lysing solution by gentle inversion of the tube. If the cells did not lyse within 5 minutes at ambient temperature to give an almost clear, viscous mixture, the lysate was incubated at $65 \sim 70^{\circ} \mathrm{C}$ for $5 \sim 30$ minutes with periodic inversion of the tube until com- 
plete lysis was obtained. The cleared lysate then was treated as described by KADO and Liu' ${ }^{13}$ ) (extraction with phenol - chloroform solution, centrifugation in an Eppendorf model 5412 microfuge, and gel electrophoresis of samples from the aqueous layer) for the detection of plasmid DNA.

Plasmid DNA Isolation Procedure

The procedure of BiBB et al. ${ }^{14)}$ was used for the isolation of plasmid DNA on a large scale and its purification by $\mathrm{CsCl}$ gradient centrifugation in the presence of ethidium bromide. Their procedure was modified as follows for use with S. erythreus. TE buffer containing $15 \%$ sucrose was used to wash the mycelia and to suspend them for incubation with lysozyme; $10 \%$ SDS in TE at a final concentration of $1.1 \%$ was used to lyse the cells by gentle inversion of the mixture at ambient temperature until the lysate had almost completely cleared before adding the $5 \mathrm{M}$ solution of $\mathrm{NaCl}$; the precipitation with PEG 6000 was done for periods between 4 and 16 hours at $4^{\circ} \mathrm{C}$; the final concentration of $\mathrm{CsCl}$ was $10.35 \mathrm{~g}$ per $10 \mathrm{ml}$ of the DNA-PEG solution in TES; the concentration of ethidium bromide was $800 \mu \mathrm{g} / \mathrm{ml}$; gradients were centrifuged in a Beckman Ti 50 rotor at 38,000 rpm for 48 hours in a Beckman L3-50 ultracentrifuge and the plasmid band collected under UV irradiation; ethidium bromide was removed by extraction with iso-propanol saturated with $\mathrm{CsCl}(50 \% \mathrm{w} / \mathrm{v})$ in TE buffer; plasmid DNA was precipitated by addition of two volumes of water and adding six volumes of ice-cold ethanol. After standing overnight at $-20^{\circ} \mathrm{C}$, the precipitated DNA was recovered by centrifugation at $10,000 \mathrm{rpm}$ at $-10^{\circ} \mathrm{C}$ for 30 minutes. The supernatant was removed and the DNA precipitate was dissolved in DNA buffer and stored at $4^{\circ} \mathrm{C}$. DEP (to $0.1 \% \mathrm{v} / \mathrm{v}$ ) was added to the solutions for long term storage.

Electron Microscopy

DNA samples were prepared for electron microscopy by the formamide method of DAvis et al..$^{15}$ and viewed with a Hitachi HS-9 electron microscope.

Restriction Endonuclease Digests

The endonucleases were obtained from Biotec, Inc., Madison, WI or from Bethesda Research Laboratories, Inc., Rockville, MD. All enzyme assays were done in $50 \mu \mathrm{l}$ of the buffer specified commercially at $37^{\circ} \mathrm{C}$ for 16 hours using excess enzyme, the enzyme reaction stopped by brief heating to $70^{\circ} \mathrm{C}$, and the reaction mixture analyzed by horizontal gel electrophoresis. Plasmid DNA used for the endonuclease digests was isolated from the band in horizontal agarose gels by electroelution, or from the vertical agarose tube gels by excision of the band followed by its mixture directly with the enzyme digest buffer.

\section{Results and Discussion}

The presence of plasmid DNA in the wild-type strain of S. erythreus NRRL 2338 was established by two methods. The rapid procedure of KADO and $\operatorname{LIU}^{13)}$ for the detection of plasmid DNA was modified for use with S. erythreus NRRL 2338 by brief treatment of the mycelial mass with lysozyme before lysing it with the alkaline solution of SDS. The period of lysozyme treatment usually was $10 \sim 15$ minutes, although some strains required a longer time for the cell walls to swell and weaken. The endpoint was judged by the change in the appearance of the mycelial cells; a flocculant and free-flowing cell suspension was optimum. The age of the cultures affected the susceptibility of the cells to lysozyme as well as the yield of plasmid DNA. Older cultures that had just entered the stationary growth phase gave the best results. Growth medium was not critical since either YEME-sucrose or TSB media proved effective. By this procedure we could detect at least five different bands of cccDNA upon electrophoresis in horizontal $0.7 \%$ agarose gels (Fig. 1-A).

We confirmed the presence of plasmid DNA in S. erythreus NRRL 2338 by large scale isolation using the PEG precipitation method of HuMPHREYs et al. ${ }^{16)}$ as adapted by BiBB et al. ${ }^{14)}$ The resulting crude plasmid DNA was purified by two cycles of $\mathrm{CsCl}$-ethidium bromide gradient centrifugation, which yielded $10 \sim 20 \mu \mathrm{g}$ of cccDNA per $500 \mathrm{ml}$ of YEME-sucrose grown mycelial cells. Electrophoresis of a 
Fig. 1. Analysis of the plasmid DNA of wild-type and variants of S. erythreus NRRL 2338 by agarose gel electrophoresis.

$A_{1}$ and $A_{2}$ : plasmid DNA of wild-type strain obtained by the method of KADO and LiU ${ }^{13}$ ) (chr, chromosomal DNA; 6, the large, ca. 94 Mdal plasmid). B: the $52 \mathrm{Mdal}$ plasmid from $S$. fradiae ATCC 10745 (bar.) C: plasmid DNA from the variant strain obtained by treatment with ethidium bromide. The second-fastest running band (parallel bars) from the bottom consists of two plasmids, of which the upper one is not present in the parent strain. D: plasmid DNA from the variant strain obtained by treatment with acridine orange. ${ }^{*} \mathrm{E}$ : plasmid DNA of the wild-type strain obtained by the method of BiBB et al. ${ }^{14)}$ and separated by electrophoresis in a vertical tube in low gelling temperature agarose. The numbers identify the pSE 1-5 plasmids (see text).

* All of the plasmids found in the parent strain are absent in this non-sporulating variant, except for pSE1.

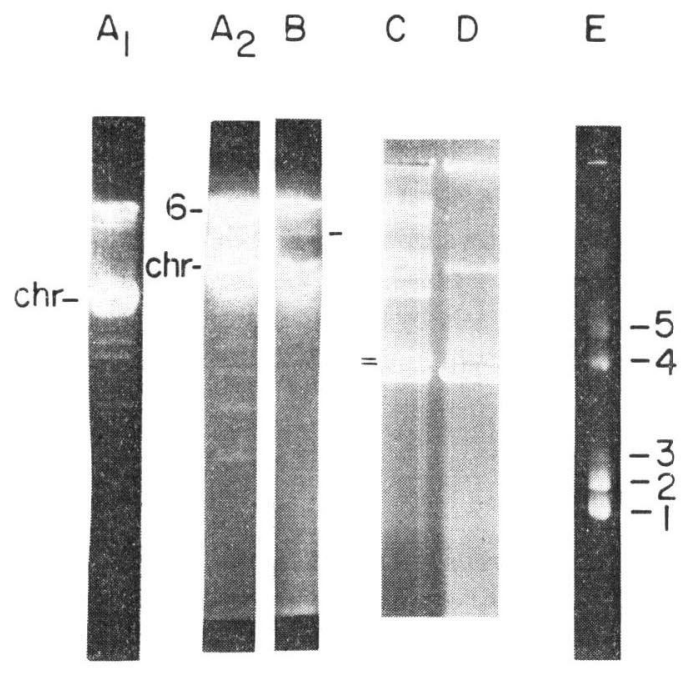

Fig. 2. Two-dimensional horizontal agarose gel electrophoresis of the total plasmid DNA from $S$. erythreus NRRL 2338.

Plasmid DNA was first electrophoresed in $0.7 \%$ agarose at 2 volts $/ \mathrm{cm}$ (A), stained with ethidium bromide for 2 hours, exposed to $300 \mathrm{~nm}$ UV light for 30 minutes, and then re-run in $0.8 \%$ agarose at 3.5 volts $/ \mathrm{cm}(\mathrm{B})$. The + symbol indicates ocDNA; the $\wedge$ indicates cccDNA; and the $\rightarrow$ indicates chromosomal or linear DNA.

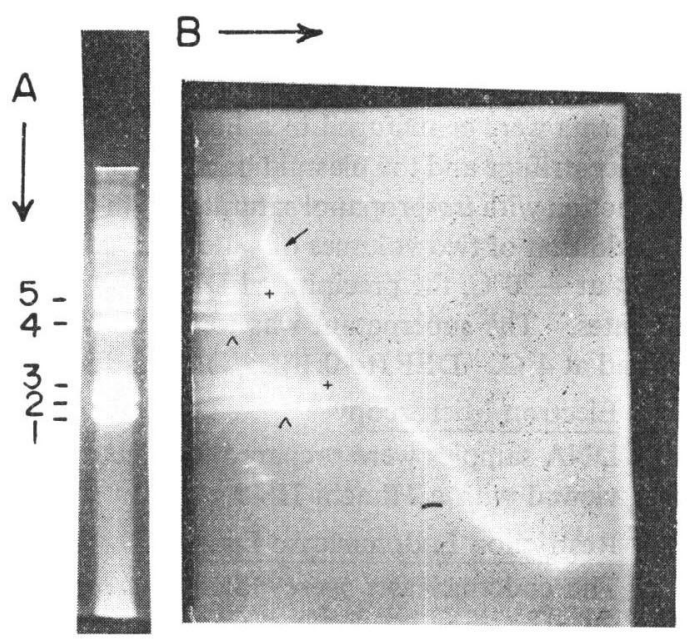

sample of this material in $0.75 \%$ low gelling temperature agarose vertical tube gels in $E$ buffer revealed several distinct bands of DNA (Fig. 1-E).

We studied the five fastest-running bands of DNA in the electrophoregrams by two methods to establish that they are plasmid DNA and to determine their size. Two-dimensional agarose gel elec-

trophoresis can distinguish among the linear, open-circle and supercoiled forms of DNA. ${ }^{17}$ ) If the agarose concentration and voltage gradient are slightly greater in the second dimension, the linear form will migrate faster than the circular forms and thus its resultant vector will be almost on the diagonal of the second dimension gel. The supercoiled form will migrate slower in the second dimension and will be preceded slightly by the open-circular form that was formed from it upon nicking by exposure to ultraviolet light during photography of the ethidium bromide stained gel. Open-circular forms present in the first dimension gel track are not affected by the ultraviolet light and their resultant vector will also be near the diagonal of the second dimension gel. Two-dimensional gel electrophoresis of the total plasmid DNA from S. erythreus NRRL 2338 (Fig. 2) shows that the five fastest migrating bands are cccDNA, whereas the sixth and seventh bands from the bottom contain a large amount of open-circle DNA. Therefore, the five lowest cccDNA bands were designated as pSE1, pSE2, pSE3, pSE4 and pSE5 in Fig. $1-\mathrm{E}$. 
Fig. 3. Electron microphotographs of single plasmid DNA from S. erythreus NRRL 2338.

Three plasmids, A (pSE1), B (pSE2) and C (pSE4) are in their open-circle forms. The large plasmid, $\mathrm{D}$, is in a relaxed form whose outermost contour is indicated by the arrows.

A

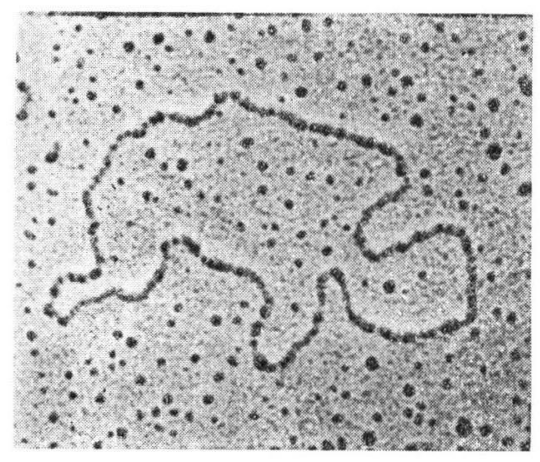

C

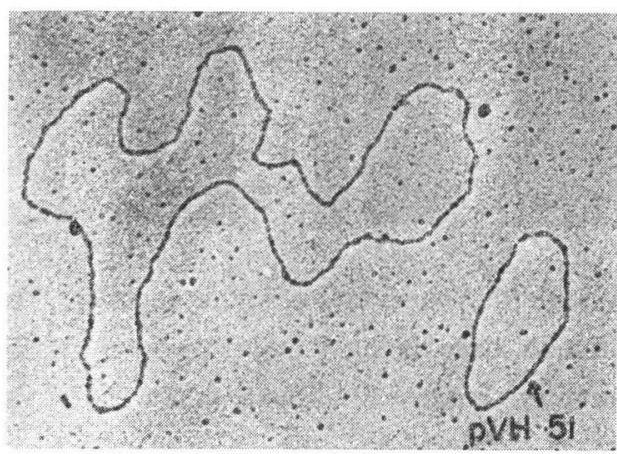

B

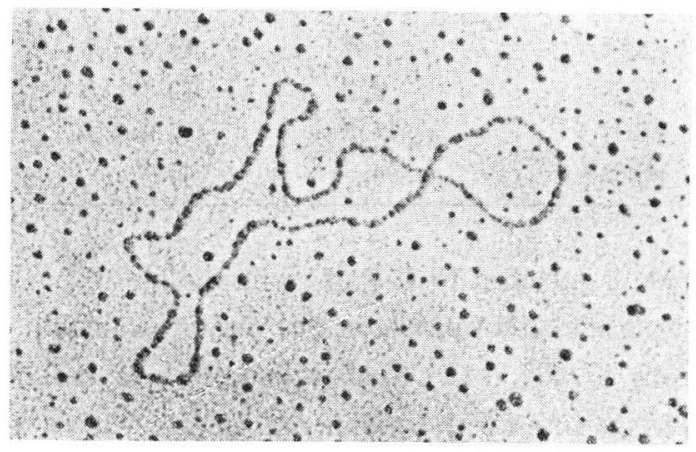

D

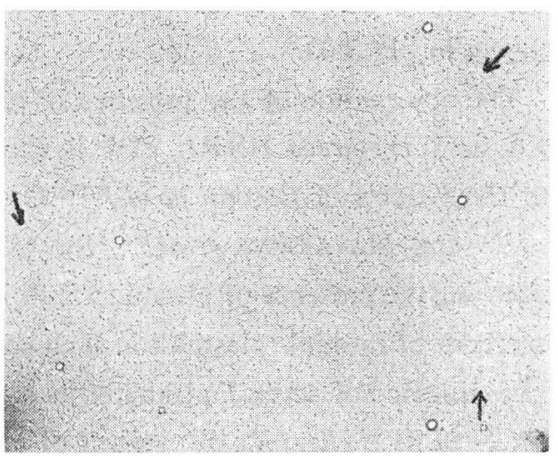

Electron microscopic analysis of samples of the pSE1, pSE2 and pSE4 plasmids confirmed that they are plasmid DNA (Fig. 3). The molecular weights of these plasmids, as determined from their contour lengths using the 2.1 Mdal pVH51 plasmid as a standard, are listed in Table 1.

We also have obtained evidence for the presence of a large plasmid in S. erythreus NRRL 2338, appearing as a faint band just below the origin on $0.7 \%$ agarose gels (Fig. 1-A). The 52 Mdal plasmid of S. fradiae ATCC $10745,{ }^{\text {B) }}$ for comparison (Fig. 1-B), ran ahead of the large S. erythreus plasmid, which suggests that the size of the latter is between 70 and 100 megadaltons. Contour length measurement of the large plasmid, taken from an electron microphotograph of the total DNA of S. erythreus NRRL 2338 (Fig. 3-D), was consistent with a molecular weight of ca. 94 Mdal.

We determined the digestion pattern of four of the S. erythreus NRRL 2338 plasmids with three endonucleases. The results (Fig. 4) show that EcoR1 cut pSE1 twice, pSE2 and pSE4 once, and pSE6 nine times; HindIII cut pSE1 once, pSE2 and pSE4 twice; BamH1 cut pSE1 twice, pSE2 three times and pSE4 eight times. pSE5 was proven to be a dimer of pSE1 by the endonuclease digestion data and other results; similarly, pSE3 may be related to pSE2 (data not shown). These and other data from restriction endonuclease mapping of the plasmids, which is in progress, reveal that pSE1 and pSE2 have similar BamH1 and HindIII restriction fragments. pSE2 thus is related to pSE1 by the addition of a $4.6 \mathrm{Mdal}$ DNA fragment and one more recognition site for each of the two enzymes.

Treatment of the wild-type strain of S. erythreus NRRL 2338 with sublethal levels of ethidium bromide in liquid culture resulted in a variant blocked in the biosynthetic pathway at the step where my- 
Table 1. Molecular weights of the plasmids from $S$. erythreus NRRL 2338.

\begin{tabular}{l|r|r}
\hline Plasmid & $\begin{array}{c}\text { Molecular } \\
\text { weight } \\
\times 10^{-6}\end{array}$ & $\mathrm{~Kb}$ \\
\hline $\mathrm{pSE1}$ & 7.4 & 11.04 \\
$\mathrm{pSE2}$ & 8.2 & 12.34 \\
$\mathrm{pSE4}$ & 11.7 & 17.46 \\
$\mathrm{pSE6}$ & $\mathrm{ca} .94$ & 140.3 \\
\hline
\end{tabular}

carose is attached to $\mathrm{C}-3$ of erythronolide $\mathrm{B}^{11)}$. The plasmid DNA profile of this variant strain is shown in Fig. 1-C. Similar treatment of the wild-type strain with acridine orange gave a variant that produces $2 \sim 3$ fold more erythromycin A than the parental strain. Its plasmid profile is shown in Fig. 1-D.

The observation of the presence of plasmid DNA in S. erythreus NRRL 2338 is consistent with the reports of OMMURA et al., ${ }^{\theta, 12)}$ OKANISHI et al. ${ }^{18)}$ and HAYAKAWA et al. ${ }^{19)}$, for example, concerning the presence of plasmid DNA in other antibiotic-producing species of streptomycetes. The occurrence of multiple plasmids in such bacteria is not common, since there are only two other reports of the presence of several plasmids in one species of streptomycetes. ${ }^{20,25)}$ One of these cases, the SLP1.1 - SL.P1.6 plasmids of variants of S. lividans ${ }^{20)}$ has been shown to originate from S. coelicolor by excision of chromosomal DNA sequences and is detectable after the plasmids transfer to S. lividans. ${ }^{21)}$

Plasmid structural changes related to phenotypic changes in macrolide producing streptomycetes has been reported by SCHREMPF and GoEBEL with the leucomycin producing strain of S. reticuli. ${ }^{22)}$ We have encountered a similar phenomenon with S. erythreus NRRL 2338. The marked variations in plasmid content (Fig. 1-C and 1-D) with changes in the antibiotic production phenotype must be judged as merely circumstantial at our present level of understanding of this system. Nonetheless, even though they must not be construed to suggest that any of the structural genes for erythromycin biosynthesis are located on the pSE1 - pSE6 plasmids, they do suggest that continued study of the question of the involvement of plasmid DNA in the biosynthesis of this macrolide is a worthwhile goal.

\section{Addendum}

Professor S. ŌMURA and his co-workers have confirmed the presence of multiple plasmids in the NRRL 2338 strain of S. erythreus (S. ŌMURA, unpublished results). Yet we and they ${ }^{12)}$ have not found plasmid DNA in several other erythromycin-producing strains of S. erythreus.

\section{Acknowledgements}

We thank Dr. David Hopwood, John Innes Institute, Norwich, England for advice concerning the use of the two-dimensional gel electrophoresis technique and CAROL MCCALL for the electron microphotographs. We are especially grateful to Drs. JANET WeSTPHELING and KeNichi KomATSU for valuable technical advice and 
stimulating discussions concerning the molecular genetics of streptomycetes. This research was supported in part by grants from the National Institutes of Health (AI 10076). The sabbatical leave of C. R. HutcHINSON in the laboratory of J. E. DAviES was supported by a Research Career Development Award from the National Institute of Health (CA 00253).

\section{References}

1) Okanishi, M.; T. Ohta \& H. Umezawa: Possible control of formation of aerial mycelium and antibiotic production in Streptomyces by episomic factors. J. Antibiotics 23: 45 47, 1970

2) Sankaran, L. \& B. M. Pogell: Biosynthesis of puromycin in Streptomyces alboniger: Regulation and properties of $O$-demethylpuromycin $O$-methyltransferase. Antimicr. Agents \& Chemoth. 8: 721 732, 1975

3) Shaw, P. D. \& J. Piwowarski: Effect of ethidium bromide and acriflavine on streptomycin production by Streptomyces bikiniensis. J. Antibiotics 30: 404 408, 1977

4) Boronin, A. M. \& L. G. Sadovnikova: Elimination by acridine dyes of oxytetracycline resistance in Actinomyces rimosus. Genetika 8: 174 176, 1972

5) OchI, K. \& E. Katz: The possible involvement of a plasmid in actinomycin synthesis by Streptomyces parvulus and Streptomyces antibioticus. J. Antibiotics 31: 1143 1148, 1978

6) Yagisawa, M.; T.-S. R. Huang \& J. E. Davies: Possible involvement of plasmids in biosynthesis of neomycin. J. Antibiotics 31: 809 813, 1978

7) Akagawa, H.; M. OKanishi \& H. Umezawa: A plasmid involved in chloramphenicol production in Streptomyces venezuelae: Evidence from genetic mapping. J. Gen. Microbiol. 90: 336 346, 1975

8) Akagawa, H.; M. OKanishi \& H. Umezawa: Genetics and biochemical studies of chloramphenicol nonproducing mutants of Streptomyces venezuelae carrying plasmid. J. Antibiotics 32: 610 620, 1979

9) Ömura, S.; H. IKeda \& C. KiтAo: The detection of a plasmid in Streptomyces ambofaciens KA-1028 and its possible involvement in spiramycin production. J. Antibiotics 32: 1058 1060, 1979

10) Kirby, R. \& D. A. Hopwood: Genetic determination of methylenomycin synthesis by the SCPI plasmid of Streptomyces coelicolor A3 (2). J. Gen. Microbiol. 98: 239 252, 1977

11) Corcoran, J. W.: Biochemical mechanisms in the biosynthesis of the erythromycins. Antibiotics. IV. Biosynthesis. ed. by J. W. Corcoran, pp. 132 174, Springer-Verlag, Berlin, Heidelberg, 1981

12) ÖmURA, S.; H. IKeda \& H. TANAKA: Extraction and characterization of plasmids from macrolide antibiotic producing streptomycetes. J. Antibiotics 34: 478 482, 1981

13) KADO, C. I. \& S.-T. Lru: Rapid procedure for detection and isolation of large and small plasmids. J. Bacteriol. 145: 1365 1373, 1981

14) Bibe, M. J.; R. F. Freeman \& D. A. Hopwood: Physical and genetical characterization of a second sex factor, SCP2, for Streptomyces coelicolor A3 (2). Molec. Gen. Genet. 154: 155 166, 1977

15) Davis, R. W.; M. N. Simon \& N. Davidson: Electron microscope heteroduplex methods for mapping regions of base sequence homology in nucleic acids. Methods Enzymol. 21D: 413 428, 1971

16) Humphreys, G. O.; G. A. Willshaw \& E. S. Anderson: A simple method for the preparation of large quantities of pure plasmid DNA. Biochim. Biophys. Acta 383: 457 463, 1975

17) Hintermann, G.; H.-M. Fischer, R. Cameri \& R. Hütter: Simple procedure for distinguishing ccc, oc and $\mathrm{L}$ forms of plasmid DNA by agarose gel electrophoresis. Plasmid 5: $371 \sim 373,1981$

18) OKanishi, M.; T. Manome \& H. Umezawa: Isolation and characterization of plasmid DNAs in Actinomycetes. J. Antibiotics 33: 88 91, 1980

19) Hayakawa, T.; N. Ōtake, H. Yonehara, T. TAnaka \& K. SaKaguchi: Isolation and characterization of plasmids from Streptomyces. J. Antibiotics 32: 1348 1350, 1979

20) Hopwood, D. A.; M. J. Bibb, J. M. Ward \& J. Westpheling: Plasmids in Streptomyces coelicolor and related species. Plasmids of Medical, Environmental and Commercial Importance, ed. by K. N. Timmis \& A. PüHLER, pp. 245 258, Elsevier/North-Holland, New York, 1979

21) Bibb, M. J.; J. M. WARd, T. Kieser, S. M. Cohen \& D. A. Hopwood: Excision of chromosomal DNA sequences from $S$. coelicolor forms a novel family of plasmids detectable in Streptomyces lividans. Mol. Gen. Genet. 184: 230 240, 1981

22) Schrempf, H. \& W. Goebel: Functions of plasmid genes in Streptomyces reticuli. Plasmids of Medical, Environmental and Commercial Importance, ed. by K. N. TImmIS \& A. PÜHLER, pp. 259 270, Elsevier/ North-Holland, New York, 1979

23) McDonell, M. W.; M. N. Simon \& F. W. Studier: Analysis of restriction fragments of T7 DNA and 
determination of molecular weights by electrophoresis in neutral and alkaline gels. J. Mol. Biol. 110:119 146,1977

24) OKanishi, M.; K. Suzukı \& H. Umezawa: Formation and reversion of streptomycete protoplasts. Cultural condition and morphological study. J. Gen. Microbiol. 80: 389 400, 1974

25) Hotta, K.; N. Saito \& Y. Okami: Studies on new aminoglycoside antibiotics, istamycins, from an actinomycete isolated from a marine environment. J. Antibiotics 32: 1502 1509, 1980 